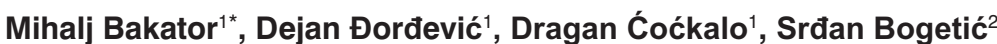

${ }^{1}$ University of Novi Sad, Technical Faculty "Mihajlo Pupin", Zrenjanin, Serbia

${ }^{2}$ Belgrade Business Academy of Vocational Studies, Belgrade, Serbia

\title{
The Impact of Consumer-Company Relationships on Brand Loyalty
}

DOI: 10.7595/management.fon.2019.0016

Abstract:

Research Question: In this paper the effect of consumers' relationship towards a company on brand loyalty is analysed. Motivation: The main goal is to determine if consumers' relationship towards a company develops brand loyalty. In addition, consumer-brand relationships, consumer-product relationships, brand trust and brand relationship quality are observed. This is important for defining complex relationships between companies, consumers and brands. Brand loyalty is the result of marketing, management and public relations practices. This thorough research provides a substantial insight into this domain. The number of studies that address several marketing management constructs in this form is low. Therefore, this approach is innovative from that viewpoint. Idea: The main idea is to analyse the complex relationships between the above-mentioned constructs and to highlight key factors while taking into consideration the integrity of the analysed data. Data: For this research, the data was collected via structured survey. The sample size of 407 included male and female consumers, aged from 15 to 65, from the major cities in Serbia. Potential biases were taken into consideration when undertaking data analysis. Tools: Conclusions were drawn from the extensive data analysis that included OLS regression analysis, (with and without control parameters), correlation analysis, reliability test, and tests for multicollinearity, heteroscedasticity and autocorrelation. Findings: The results indicate that there is a strong link between consumers' relationship towards a company and brand loyalty. In addition, the links between the mediating constructs shed light on the complexity of developing relationships with consumers. Contribution: This study contributes to the existing body of literature and expands the view on consumer-company relationships from the aspect of brand and marketing management and management overall.

Keywords: consumer-company relationships, brand loyalty, brand relationship quality, public relations, business performance

JEL Classification: M31, M21, D40

\section{Introduction}

When examining brand loyalty, it is important to quote the findings of Moller Jensen and Hansen (2006). In their study, it is argued that brand loyalty should be investigated through consumers who had a multiple choice of brands, and not just the one brand they use. If only one brand is present on a specific market, it may induce partial or non-organic consumer brand loyalty (Moller Jensen \& Hansen, 2006). Therefore, in this research, the participants had a choice from a wide variety of international brands, and they could write down other brands as well. This way, the non-organic consumer brand loyalty is managed, so it does not severely affect the results. Furthermore, Veloutsou (2009) perfectly addressed consumer behaviour, and noted that there are different emotions towards a brand. In addition, he also argued that consumers can develop strong emotions towards a company that further enhances brand loyalty. Matzler, Grabner-Krauter and Bidmon (2008) analysed various literature on brand loyalty and noted that brand loyalty is one of the central factors around which companies achieve competitiveness and generate advantageous positions on the market. Brand loyalty is stronger, and more stable for companies that achieved market leadership status (Dekimpe, Steenkamp, Mellens \& Abeele, 1997). Without strong brand loyalty, companies can expect a hard time to increase sales volume (Lin, Wu \& Wang, 2000). Now, companies have to position themselves on the market in a way that they will satisfy incoming customers' needs (Djordjevic, Cockalo \& Bogetic, 2016). In 
the same study it was discussed that changes on the market affect enterprise management. Furthermore, in order to gain customers, and to positively affect the consumer-company relationship, companies have to focus not only on the internal but on the external environment as well. For long-term sustainability and competitiveness, companies have to change their business models from pure profit-focused to environmentfocused (Kitic, Kostic-Stankovic, Cvijovic \& Lecic-Cvetkovic, 2015). This means that corporate social responsibility (CSR) should be taken into consideration when aiming for higher financial performance and increased competitiveness on the market (Vlastelica Bakic, Cicvaric Kostic \& Neskovic, 2015). Companies use various forms of marketing communication such as advertising and public relations through different media outlets in order to increase brand awareness, create brand image, and connect with the consumers (Bakator, Boric \& Paunovic, 2017). From here, dynamic relationships arise between consumers and companies.

The main goal of this research is to identify influencing factors on brand loyalty development, More precisely, the effect of consumers' relationship towards a company on the development of brand loyalty is analysed. As consumer-company relationships are complex, additional marketing constructs are investigated such as consumer-brand relationships, consumer-product relationships, brand trust and brand relationship quality. The main reason behind this research is the necessity to highlight the potential causal relations between the above-mentioned factors. After a thorough investigation into a large body of literature in the domain of consumer-company relationships and brand loyalty, it was found that the majority of these studies address only up to three constructs, thus leaving a small gap where a multi-construct approach is welcomed. This current paper provides exactly that, a multi-construct approach to consumer-company relationship and brand loyalty development.

The data for this study were obtained through surveys. It is important to note that the terms consumers and customers are used interchangeably due to literature analysis. However, in this present study, the focus is on consumers and customers as users of products and/or services.

The data analysis included descriptive statistics, reliability test, OLS regression analysis, correlation analysis, and tests for multicollinearity, heteroscedasticity, and autocorrelation. The paper starts with the examination of literature in the domain of brand loyalty, consumer behaviour, brand trust, and consumer-company relationships. In the next section, the research methodology is presented. The fourth section presents the obtained results from the conducted analyses. Afterwards, the results are discussed, the contribution of the study is outlined, and the limitations of the study are addressed. In the final section conclusions are drawn, and guidelines for future research are suggested.

\section{Theory and Hypotheses Development}

\subsection{Relationships towards a company and brand trust}

Chen and Myagmarsuren (2011) investigated the relationships between brand equity, relationship value, and customer loyalty. Their findings suggested that high relationship values between consumers and companies, increased brand equity. It is certain that developing strong relationships with a company is beneficial for brand trust (Kuikka \& Laukkanen, 2012). Early research of Bhattacharya and Sen (2003) discussed that consumer-company identification has an important role in developing brand loyalty. Additionally, this relationship is important for managers, as consumer-company relationships and its influence on brand loyalty can help understand the possibilities and limits of relationship-building activities and strategies. Consumers tend to connect with some brands, while not with others. It was noted that various levels of attraction and self-identification with the company could affect brand loyalty development (Elbedweihy, Jayawardhena, Elsharnouby \& Elsharnouby, 2016). Therefore, based on previous findings, it is safe to assume that consumers' relationships towards a company are an important marketing management construct for managers and companies, as these constructs can affect long-term business performance.

In the modern marketing environment, consumers are influenced by many factors that lead to behaviours on the market that do not have patterns, and are hard to predict (Alavuk, Jevtic \& Petrevska, 2015). Prior research suggests that building relationships towards a company is an important process where overall business performance is affected (Kim, Park \& Kim, 2014). It is evident that the consumer-company relationships and their effect on brand loyalty strength play an important role in achieving adequate business performance. Companies strive towards loyal customers, and are eager to develop strong customer relationships, as loyalty is crucial for a competitive advantage on the market (Aggarwal, 2004). Loyalty can 
be achieved through customer satisfaction, thus companies have to address the needs and wishes of their customers (Bakator, Boric \& Paunovic, 2017). Certainly, consumer-company relationships are a complex construct where achieving brand loyalty is the main goal of consumer-relationship building strategies. Taking into consideration previous findings, the following null, and alternative hypotheses are suggested:

$\mathrm{H}_{0}$ : Developing a positive relationship towards a company increases brand loyalty

$\mathrm{H}_{\mathrm{a}}$ : Developing a positive relationship towards a company does not affect brand loyalty.

On dynamic markets, consumers' relationships with companies and their effect on brand loyalty can define future business performance, and strongly affect business excellence. This has been examined by Theng, Parsons and Yap (2013), where the existence of moderate correlation between brand trust, and consumerproduct relationships was analysed. Brand and product relationships build strong brand identities. Relationship development with companies is a strategic process where companies endure various feedback from existing customers and consumers (Rauyruen \& Miller, 2007). Consumer loyalty towards a brand is one of the results of strong relationships between consumers and companies. However, do relationships towards a company indicate strong consumer-product relationships? The complexity of human perceptions, affections and overall emotions towards objects demands as much investigation as possible. The forementioned research findings, and the mentioned comprehensive descriptions of the examined constructs, provide a strong base for the following auxiliary hypotheses:

$\mathrm{H}_{1}$ : Strong relationships towards a company positively influence consumer-product relationships.

$\mathrm{H}_{2}$ : Strong relationships towards a company positively influence brand trust.

$\mathrm{H}_{3}$ : Strong relationships towards a company positively influence consumer-brand relationships.

\subsection{Consumer-brand and consumer-product relationships}

Customer satisfaction is valuable for developing consumer-brand relationships (Muyammil, Haffey \& Riaz, 2010). In addition, earlier findings of Smit, Bronner \& Tolboom, (2007) note that the consumer-brand relationship resonates through business performance and it influences consumer-product relationships. Brand equity and strong consumer-brand relationships positively affect the marketing environment in the companies' favour (Keller, 2009). This is presented through more effective marketing communications, and most importantly, higher profits. Furthermore, Fetscherin and Heinrich (2014) investigated consumer-brand relationships, and described that strong feelings towards a brand, and a strong brand relationship, result in brand love. One year later, after a complex research of literature on this subject, Fetscherin and Heinrich (2015) note that storytelling plays an important role when it comes to brand relationship development. Breivik and Thorbjornsen (2008) suggest that brand relationship quality affects deeper dimensions of consumer-brand relationships. Brand relationship quality includes three interconnected factors that a consumer expresses towards a brand. These factors are affection and socio-emotion, behaviour, and cognition (Francisco-Maffezzolli, Semprebon, \& Muller Prado, 2014). Now, brand relationship quality can alsobe described as an indicator which defines the strength and depth of a consumer-brand relationship (Hudson, Roth, Madden \& Hudson, 2015). However, Smit, Bronner \& Tolboom (2007) argue that consumer-brand relationships cannot exist between all brands, and all consumers. Some brands are more suited to develop relationships with consumers, while other brands may lack personality (Aaker, Fournier \& Brasel, 2004). It is clear that emotions towards brands require further investigation as they can affect consumer behaviour. From the company's point of view, developing good relationships with consumers is an imperative for long-term success. Therefore, with the goal to investigate these relationships, additional auxiliary hypotheses are proposed:

$\mathrm{H}_{4}$ : Strong consumer-product relationships positively influence consumer-brand relationships.

$\mathrm{H}_{5}$ : Strong consumer-product relationships positively influence brand trust.

$\mathrm{H}_{6}$ : Strong consumer-product relationships positively influence brand relationship quality.

\subsection{Brand loyalty and managing consumer behaviour}

Brand image, and brand loyalty are often portrayed as complementary dimensions that influence consumer behaviour towards buying a specific brand (Kotler \& Keller, 2016). Brand loyalty was described as a consumers' mind-set that will result in repetitious purchase of the same brand (Severi \& Ling, 2013). Similarly, prior research of Chaudhuri and Holbrook (2001) described brand loyalty as a preference for repeated purchase of products or services from the same brand. Consumer loyalty, and good relationships between consumers and companies for achieving a competitive advantage on the market (Djordjevic, Cockalo, \& 
Bogetic, 2016). Punniyamoorthy and Prasanna Mohan Raj, (2007) pointed out that brand loyalty should be measured not only by the frequency of repurchase, but by the customers' attitude, and satisfaction as well. Therefore, in this research the questions are designed to avoid "crippling" miss-measurements, and are focused on the brand as a whole, rather than just on purchasing frequency. It is evident that consumercompany relationships are a key influential factor when developing marketing strategies (Kotler \& Keller, 2016; Russell-Bennett, McColl-Kennedy \& Coote, 2007). Based on the reviewed literature, additional auxiliary hypotheses are suggested:

$\mathrm{H}_{7}$ : Strong consumer-brand relationships positively influence brand loyalty.

$\mathrm{H}_{8}$ : Strong brand trust positively influences brand loyalty.

$\mathrm{H}_{9}$ : High brand relationship quality positively influences brand loyalty.

Further, in Figure 1, the research framework is presented and it depicts the observed relationships between the main and mediating constructs.

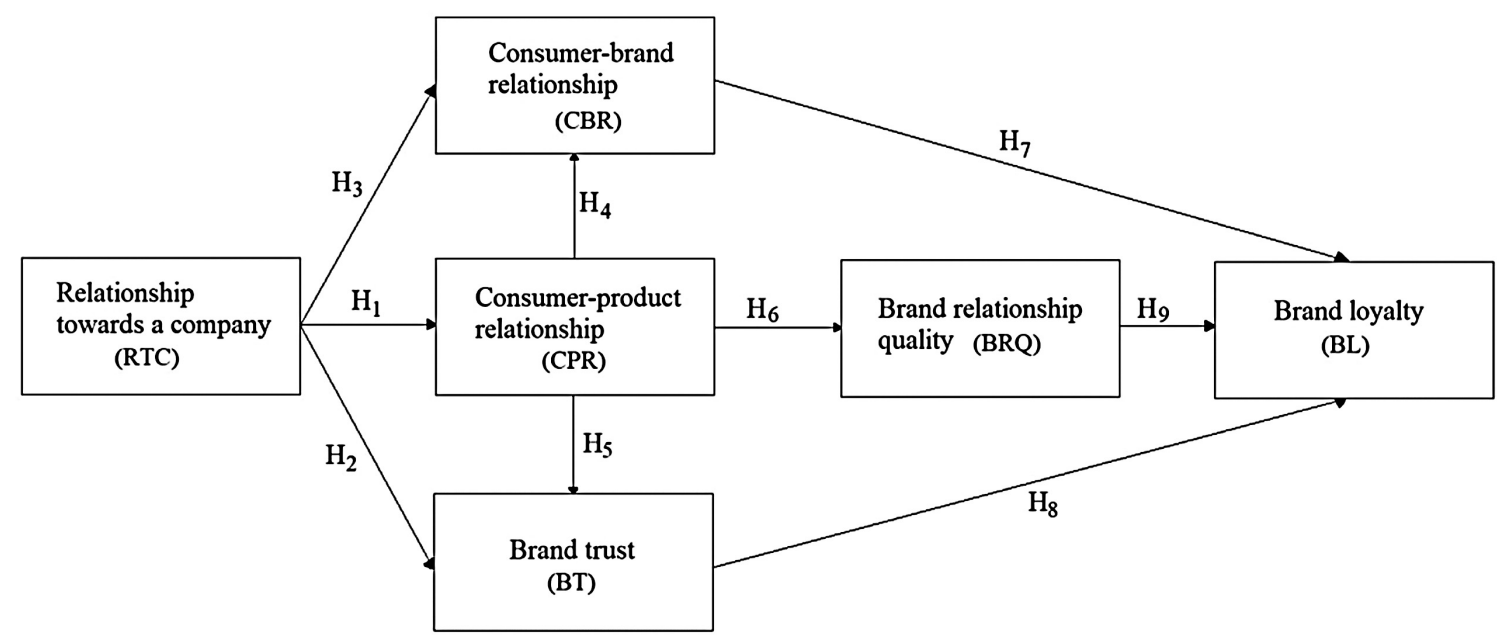

Figure 1: Research framework

\section{Research Methodology}

The survey for this study was designed and based on similar research in this domain (Buil, de Chernatony \& Martinez, 2013; Chen \& Ann, 2014; Habibi, Laroche \& Richard, 2014; Mishra, Bhusan \& Dash, 2014; Park \& Kim, 2014; Zarantonello, 2016). These papers examined various aspects of brand loyalty, brand trust, perceived quality, perceived value, and other constructs in the domain of marketing, consumer-company relationships, brand management and management overall. The surveys in these research articles are well balanced, thus they provide adequate survey items for developing a reliable survey for this present research. A seven-point Likert scale was used for twenty-five (25) items distributed across six (6) constructs. According to Brown (2011), a Likert scale type survey is sufficient for this type of research. In addition, credible studies in this domain were conducted where the data was collected through surveys with Likert scale items (Ramaseshan \& Tsao, 2007; Vigneron \& Johnson, 2017). In Table 1 the research items are presented. 


\begin{tabular}{|c|c|}
\hline Dimension & \\
\hline $\begin{array}{l}\text { Relationship towards } \\
\text { a company (RTC) }\end{array}$ & $\begin{array}{l}\text { The company under this brand understands my needs. } \\
\text { The company under this brand takes into consideration my thoughts } \\
\text { about the brand. } \\
\text { I think that this company takes care of its customers and consumers. } \\
\text { I feel that the company seriously considers my feedback about the } \\
\text { products. } \\
\text { I feel that the company shares significant information with me. }\end{array}$ \\
\hline Brand loyalty (BL) & $\begin{array}{l}\text { I find myself loyal to this brand. } \\
\text { I'm ready to pay more for this particular brand. } \\
\text { I will go to another store if I have to, to buy this brand. } \\
\text { This brand is my first choice. }\end{array}$ \\
\hline $\begin{array}{l}\text { Consumer-brand } \\
\text { relationship (CBR) }\end{array}$ & $\begin{array}{l}\text { I appreciate the history of this brand, } \\
\text { If I had to buy another product, I would buy from this brand. } \\
\text { I think that this brand has the highest quality. } \\
\text { I would help in promoting this brand. }\end{array}$ \\
\hline $\begin{array}{l}\text { Consumer-product } \\
\text { relationship (CPR) }\end{array}$ & $\begin{array}{l}\text { I love the products under this brand. } \\
\text { I am proud for using the products under this brand. } \\
\text { I cherish the products under this brand. }\end{array}$ \\
\hline Brand trust (BT) & $\begin{array}{l}\text { I'm willing to pay more for this brand. } \\
\text { I'll recommend this brand to my friends. } \\
\text { I am sure that this brand is socially responsible. } \\
\text { This brand's products are good. } \\
\text { I can trust this brand. }\end{array}$ \\
\hline $\begin{array}{l}\text { Brand relationship } \\
\text { quality (BRQ) }\end{array}$ & $\begin{array}{l}\text { I find this brand honest. } \\
\text { I feel good when I use products and services under this brand. } \\
\text { This brand matches my character. } \\
\text { My image and brand's image are complementary. }\end{array}$ \\
\hline
\end{tabular}

Table 1: Research items

The research was conducted in 4 main phases. Phase 1 included extensive literature analysis, theoretical background development, and survey design. Phase 2 included distributing the surveys online. In phase 3 , the data were exported, prepared for analysis. Phase 4 included the analysis of the results, discussion, and conclusions.

\section{Results}

In Table 2, the results of the descriptive statistics are shown. For every measured construct, the sample size, the minimum, and maximum values, the mean, and the standard deviation values are presented.

\begin{tabular}{|c|c|c|c|c|c|}
\hline \multicolumn{6}{|l|}{ Descriptive statistics } \\
\hline Dimension & $\mathbf{N}$ & Min. & Max. & Mean $(\mu)$ & $\begin{array}{c}\text { Standard } \\
\text { deviation }(\sigma)\end{array}$ \\
\hline $\begin{array}{l}\text { Relationship towards a } \\
\text { company (RTC) }\end{array}$ & 407 & 1 & 7 & 4.00 & 1.80 \\
\hline Brand loyalty (BL) & 407 & 1 & 7 & 4.24 & 1.69 \\
\hline $\begin{array}{l}\text { Consumer-brand relationship } \\
\text { (CBR) }\end{array}$ & 407 & 1 & 7 & 4.10 & 1.56 \\
\hline $\begin{array}{l}\text { Consumer-product } \\
\text { relationship (CPR) }\end{array}$ & 407 & 1 & 7 & 4.10 & 1.79 \\
\hline Brand trust (BT) & 407 & 1 & 7 & 4.24 & 1.59 \\
\hline $\begin{array}{l}\text { Brand relationship quality } \\
\text { (BRQ) }\end{array}$ & 407 & 1 & 7 & 4.15 & 1.78 \\
\hline
\end{tabular}

Table 2: Results of descriptive statistics for every dimension

For every measured dimension the minimum and maximum values are 1 and 7 . Further, it can be seen, that the means of the measured dimensions vary from 4.00 to 4.24 . The standard deviations range from 1.56-1.80.

Further, the obtained sample details are given in Table 3. 


\begin{tabular}{|c|c|c|}
\hline Targeted population & \multicolumn{2}{|c|}{ over 30.000 people from the Republic of Serbia } \\
\hline Age and gender & \multicolumn{2}{|c|}{ from 15 to 65 and older; male and female } \\
\hline Education & \multicolumn{2}{|c|}{ not specified } \\
\hline Employment & \multicolumn{2}{|l|}{ not specified } \\
\hline Number of completed surveys & \multicolumn{2}{|l|}{411} \\
\hline Number of valid surveys & \multicolumn{2}{|l|}{407} \\
\hline Survey participants & \multicolumn{2}{|l|}{ anonymous } \\
\hline $\begin{array}{l}\text { Measures taken to exclude double-counting, } \\
\text { and double-participation }\end{array}$ & \multicolumn{2}{|c|}{$\begin{array}{l}\text { thorough analysis of collected data; submission } \\
\text { checks }\end{array}$} \\
\hline \multicolumn{3}{|c|}{ Obtained sample details } \\
\hline Age & $\mathbf{N}=407$ & $\%$ of total \\
\hline$<20$ & 164 & 40.3 \\
\hline $20-30$ & 163 & 40 \\
\hline $31-40$ & 57 & 14 \\
\hline $41-50$ & 19 & 4.8 \\
\hline $51-60$ & 1 & 0.2 \\
\hline 61 and older & 3 & 0.7 \\
\hline \multicolumn{3}{|l|}{ Gender } \\
\hline Male & 129 & 31.7 \\
\hline Female & 278 & 68.3 \\
\hline \multicolumn{3}{|l|}{ Employment } \\
\hline Employed & 119 & 29.3 \\
\hline Unemployed & 40 & 9.8 \\
\hline Student & 246 & 60.4 \\
\hline Retired & 2 & 0.5 \\
\hline \multicolumn{3}{|l|}{ Education } \\
\hline Elementary and secondary education & 19 & 4.7 \\
\hline High school & 204 & 50.1 \\
\hline Undergraduate degree & 150 & 36.9 \\
\hline Master's degree & 31 & 7.6 \\
\hline Magister degree & 2 & 0.5 \\
\hline Ph.D. degree & 1 & 0.2 \\
\hline
\end{tabular}

Table 3: Sample details

A majority of the sample consists of two groups: the younger than $20(40.3 \%)$ and the 20 to 30 years old $(40 \%)$. The gender structure of the sample is in favour of women $(68.3 \%)$, and a vast majority of the participants are students $(60.4 \%)$. However, to ensure that there is no bias and that the sample is representative, several statistical analyses were conducted later in the paper.

After sample details, a Cronbach's alpha reliability test was used in order to determine the internal consistency of the measured items. The results of the reliability test are given in Table 4.

\begin{tabular}{|l|c|c|}
\hline Reliability test \\
\hline Dimension & Cronbach's alpha & Number of items \\
\hline Relationship towards a company (RTC) & 0.855 & 5 \\
\hline Brand loyalty (BL) & 0.901 & 4 \\
\hline Consumer-brand relationship (CBR) & 0.812 & 4 \\
\hline Consumer-product relationship (CPR) & 0.905 & 3 \\
\hline Brand trust (BT) & 0.851 & 5 \\
\hline Brand relationship quality (BRQ) & 0.890 & 4 \\
\hline
\end{tabular}

Table 4: Results of the reliability test

The results are satisfactory as the values are over 0.8 and 0.9 . The close to 1.0 Cronbach's alpha values indicate that there were no two contradictory statements between the items in the survey. Further a heteroscedasticity test was conducted in order to ensure that the OLS will give the estimator with the smallest variance. The results of the heteroscedasticity are given in Table 5. 


\begin{tabular}{|l|c|c|}
\hline \multicolumn{2}{|c|}{ Heteroscedasticity test } \\
\hline LM (Observed value) & Breusch-Pagan test & White test \\
\hline LM (Critical value) & 0.854 & 5.306 \\
\hline DF & 3.841 & 5.992 \\
\hline p-value (Two tailed) & 1 & 2 \\
\hline alpha & 0.356 & 0.0704 \\
\hline
\end{tabular}

Table 5: Results of the heteroscedasticity test

In, addition a test for multicollinearity was conducted. The results are given in Table 6.

\begin{tabular}{|l|c|c|c|c|c|c|}
\hline Multicollinearity statistics & RTC & CPR & CBR & BRQ & BL & BT \\
\hline & 0.467 & 0.562 & 0.438 & 0.488 & 0.432 & 0.426 \\
\hline Tolerance & 2.141 & 1.779 & 2.282 & 2.050 & 2.301 & 2.348 \\
\hline $\begin{array}{l}\text { Variance Inflation } \\
\text { Factor (VIF) }\end{array}$ &
\end{tabular}

Table 6: Results of the muClticollinearity statistics

Based on the results in Table 6, it can be assumed that there is little to no multicollinearity between the observed constructs, as only a few VIF values are slightly higher than 2.3. Furthermore, with the goal to determine the relationship between the observed constructs, an OLS regression analysis was conducted. In Table 7 and Table 8, the results of the regression analysis are presented.

\begin{tabular}{|l|l|c|c|c|c|}
\hline Dependent & Independent & $\boldsymbol{\beta}=\mathbf{0 . 6 5 5}$ & St. Error & $\mathbf{R}^{\mathbf{2}}$ & ${\text { Adjusted } \mathbf{R}^{\mathbf{2}}}^{*}$ \\
\hline \multirow{3}{*}{ BL } & RTC & 0.138 & 0.038 & & \\
\cline { 2 - 4 } & CPR & 0.275 & 0.035 & \multirow{2}{*}{0.697} & \multirow{2}{*}{0.63} \\
\cline { 2 - 4 } & CBR & 0.337 & 0.045 & & \\
\cline { 2 - 4 } & BRQ & 0.225 & 0.038 & & \\
\cline { 2 - 4 } & BT & 0.306 & 0.045 & & \\
\hline
\end{tabular}

Table 7: Results of regression analysis ( $\beta$, S.E., $R^{2}$, Adjusted $R^{2}$ )

Further, additional data from the regression analysis are given in Table 8.

Table 8: Results of regression analysis (p-value, F, F Sig., Durbin-Watson value)

For the regression analysis, brand loyalty was taken as a dependent variable, and the other constructs were taken as independent variables. The $\mathrm{R}^{2}$ value of 0.697 indicates that there is a strong and positive relationship between the dependent variable, and the independent variables. The $p$-values indicate that the null hypothesis cannot be rejected. The Durbin-Watson value (DW) indicates that there is little to no autocorrelation between the variables. Here the regression equation has the form: $B L=\beta_{0}+\beta_{1} \cdot R T C+\beta_{2}$ - CPR $+\beta_{3} \cdot \mathrm{CBR}+\beta_{4} \cdot \mathrm{BRQ}+\beta_{5} \cdot \mathrm{BT}+\epsilon$. The values from Table 7 are inserted into the equation, are results is: $\mathrm{BL}=0.655+0.138 \cdot \mathrm{RTC}+0.275 \cdot \mathrm{CPR}+0.337 \cdot \mathrm{CBR}+0.225 \cdot \mathrm{BRQ}+0.306 \cdot \mathrm{BT}+\epsilon$.

Further, another OLS regression analysis was conducted based on the following regression model: $B L=\beta_{0}$ $+\beta_{1} \cdot R T C+\beta_{z} \cdot z++\epsilon$; where $z=C P R, C B R, B R Q$, and BT are presented as separate regressions. The results of this regression analysis are presented in Table 8.

\begin{tabular}{|l|l|c|c|c|c|}
\hline Dependent & Independent & p-value & F & F Sig. & $\begin{array}{c}\text { Durbin-Watson value } \\
\text { (DW) }\end{array}$ \\
\hline \multirow{3}{*}{ BL } & RTC & 0.0003 & & & \\
\cline { 2 - 3 } & CPR & 0.0004 & & \\
\cline { 2 - 3 } & CBR & $<0.0001$ & \multirow{3}{*}{184.575} & $<0.0001$ & 1.893 \\
\cline { 2 - 3 } & BRQ & $<0.0001$ & & & \\
\cline { 2 - 3 } & BT & $<0.0001$ & & & \\
\hline
\end{tabular}

Table 8: Results of the OLS regression ( $\beta, R^{2}$, p-value, S.E.) 
Next, a Spearman's correlation analysis was conducted. Instead of the Pearson's correlation analysis, a Spearman's correlation was considered as it gives more adequate results for ordinal data (Hauke \& Kossowski, 2011). The results of correlation analysis are given in Table 9.

\begin{tabular}{|l|c|c|c|c|c|c|}
\hline \multicolumn{6}{|l|}{ Correlation analysis } \\
\hline & RTC & CPR & CBR & BRQ & BL & BT \\
\hline RTC & $1.000^{\star}$ & & & & & \\
\hline CPR & $0.625^{\star}$ & $1.000^{\star}$ & & & & \\
\hline CBR & $0.621^{\star}$ & $0.682^{\star}$ & $1.000^{\star}$ & & & \\
\hline BRQ & $0.570^{\star}$ & $0.588^{\star}$ & $0.591^{\star}$ & $1.000^{\star}$ & & \\
\hline BL & $0.559^{\star}$ & $0.589^{\star}$ & $0.649^{\star}$ & $0.646^{\star}$ & $1.000^{\star}$ & \\
\hline BT & $0.536^{\star}$ & $0.559^{\star}$ & $0.554^{\star}$ & $0.576^{\star}$ & $0.664^{*}$ & $1.000^{*}$ \\
\hline *Significance: $5 \%$ & & & & \\
\hline
\end{tabular}

Table 9: Results of the correlation analysis

The correlation analysis indicates that between every measured marketing construct, there is a moderate to strong positive relationship. The lowest correlation value $(0.536)$ is between brand trust (BT) and relationship towards a company (RTC). The highest correlation value (0.682) is noted between the consumer-product relationship construct (CPR), and the consumer-brand relationship construct (CBR). Overall, the correlation analysis provided satisfactory results.

\section{Discussion}

The results of the data analyses indicate that the null hypothesis cannot be rejected, and the alternative hypothesis is rejected. Therefore, the current study has found that consumers' relationship towards companies positively influences brand loyalty. In addition, it has been found that there is a positive relationship between the consumer-brand relationships, consumer-product relationships, brand trust, and brand relationship quality. Further, the tests for multi-collinearity, autocorrelation, and heteroscedasticity are "negative" indicating that there is no multicollinearity, autocorrelation and heteroscedasticity among the observed variables.

This present paper is complementary with the findings of Kim, Morris and Swait (2008) who discussed that when a customer is satisfied, he or she favours a specific brand that has earned their loyalty. Further, the findings in this present study are similar to the findings of Delgado-Ballester and Munuera-Aleman (2000), who noted that better relationships with companies achieve higher levels of brand trust. It is certain that there is an influential relationship between the measured constructs. Similarly to the findings of (Chaudhuri \& Holbrook, 2001), this study observes that brand relationship quality, and consumer-brand relationships positively affect brand loyalty. Furthermore, the findings of this present paper are complementary to other research papers regarding brand loyalty and service quality (Hemsley-Brown \& Alnawas, 2016), brand loyalty and customer satisfaction (Torres-Moraga, Vasquez-Parraga \& Zamora-Gonzalez, 2008), brand credibility, customer loyalty (Kuikka \& Laukkanen, 2012) and consumer-brand relationships (Giovanis \& Athanasopoulou, 2018).

Next, the theoretical background provided support and adequate insight into the main issues regarding consumer-brand relationships, brand loyalty, and overall consumer behaviour. Why is this paper significant?

There is quite a number of studies published in the domain of brand loyalty, brand trust, and overall consumer behaviour. However, the number of papers that investigate the consumer-company relationship construct and brand loyalty as the main analysed dimensions is practically non-existent. Therefore, this present study significantly contributes to the existing body of literature in this domain.

What is even more significant are the managerial implications which come from the research results. The two main implications are in the domain of consumer relationship management (CRM) and brand management. First, managers should address the needs and wishes of consumers. This means statistical analysis of feedback data obtained from consumers. This will help in developing and modifying products in order to increase satisfaction rates and re-purchase rates. The optimization process of products and services has to address the detected needs of consumers. Managers have to make the optimization-till-satisfaction approach an imperative. 


\begin{abstract}
Additionally, based on the research results, managers have to develop long-term strategies in order to develop and maintain good relationships with consumers, as developing relationships towards a company further positively affect consumer-product and consumer-brand relationships. The result of this is a stronger brand trust and brand relationship quality, and an overall stronger brand loyalty. In brand management, managers have to address the relationships between consumers and products, as these are good indicators for brand loyalty development. By establishing good relationships with consumers, the company increases its potential on the market and acquires a competitive advantage.
\end{abstract}

In sum, the results in this paper provide a better understanding of the consumer-company relationships, consumer loyalty, and brand loyalty by investigating key marketing constructs. Thorough analyses were conducted over structured sample data. Managers can examine these findings, which can help them make more adequate decisions when it comes to developing brands and relationships with consumers and customers as well.

\title{
Conclusion
}

This research paper has investigated the connections between consumers' relationship towards a company, and brand loyalty through other complex constructs. The data were obtained from surveys, and were analysed using the regression analysis as well as correlation analysis. According to the results of these analyses, the auxiliary hypotheses cannot be rejected, thus the null hypothesis $\mathrm{H}_{0}$ : Developing a positive relationship towards a company, increases brand loyalty cannot be rejected and the alternative hypothesis is rejected. The regression and correlation analyses confirmed the proposed auxiliary hypotheses. The main purpose of this study was to present the consumers' relationships towards a company, and how these relationships influence consumer behaviour on the market. Additionally, the dynamic relationship of consumers and companies was presented through other constructs. Undoubtedly, this research extended the knowledge of brand loyalty, and customer-company relationships into the right direction.

Future studies are suggested and welcomed. The influential nature of different aspects of a brand on customer and consumer behaviour should also be addressed. This includes the measurement of brand love, brand integrity, and brand congruity. Additionally, the perceived product quality and perceived advertising should be added into the survey. After these future studies are conducted, it will be interesting to compare their results with this present study. The sample for future studies should also be structured and tested for biases and skewness. In addition, heteroscedasticity tests and multicollinearity test should be included. The sample should also include a minimum of 400 participants, as this will reduce the risk of skewed and bias results. Finally, a thorough meta-analysis of various studies in the domain of consumercompany relationships could be conducted. A marketing environment, as complex as it is, requires a structured and analytical approach. This will ensure that all the major dimensions are analysed according to their nature and role on the market. This present study provides a solid basis for future research.

\section{REFERENCES}

[1] Aaker, J., Fournier, S., \& Brasel, S. A. (2004). When good brands do bad. Journal of Consumer Research, 31(1), 1-16. DOI: 10.1086/383419.

[2] Aggarwal, P. (2004). The effects of brand relationship norms on consumer attitudes and behavior. Journal of Consumer Research, 31(1), 87-101. DOI: 10.1086/383426.

[3] Alavuk, Dj.., Jevtic, J., \& Petrevska, I. (2015). Sales promotion as a determining factor in the competitive position of the company. Journal of Engineering Management and Competitiveness (JEMC), 5(1), 50-54.

[4] Bakator, M., Boric, S., \& Paunovic, M. (2017). Influence of advertising on consumer-based brand loyalty. Journal of Engineering Management and Competitiveness (JEMC), 7(2), 75-83.

[5] Bhattacharya, C. B., \& Sen, S. (2003). Consumer-Company Identification: A Framework for Understanding Consumers' Relationships with Companies. Journal of Marketing, 67(2), 76-88. DOI:10.1509/jmkg.67.2.76.18609.

[6] Breivik, E., \& Thorbjørnsen, H. (2008). Consumer brand relationships: an investigation of two alternative models. Journal of the Academy of Marketing Science, 36(4), 443-472. DOI: 10.1007/s11747-008-0115Z.

[7] Brown, J. D. (2011). Likert scale items and scales of measurement. Shiken: JALT Testing \& Evaluation SIG Newsletter, 15(1), 10-14.

[8] Buil, I., de Chernatony, L., \& Martínez, E. (2013). Examining the role of advertising and sales promotions in brand equity creation. Journal of Business Research, 66(1), 115-122. DOI: 10.1016/j.jbusres.2011.07.030. 
[9] Chaudhuri, A., \& Holbrook, M. B. (2001). The chain of effects from brand trust and brand affects to brand performance: The role of brand loyalty. Journal of Marketing, 65(2), 81-93. DOI: 10.1509/jmkg.65.2.81.18255.

[10] Chen, C.-F., \& Myagmarsuren, O. (2011). Brand equity, relationship quality, relationship value, and customer loyalty: Evidence from the telecommunications services. Total Quality Management \& Business Excellence, 22(9), 957-974. DOI: 10.1080/14783363.2011.593872.

[11] Chen, C.-M., \& Ann, B.-Y. (2014). Efficiencies vs. importance-performance analysis for the leading smartphone brands of Apple, Samsung and HTC. Total Quality Management \& Business Excellence, 27(3-4), 227-249. DOI: 10.1080/14783363.2014.976937.

[12] Dekimpe, M. G., Steenkamp, J.-B., Mellens, M., \& Abeele, P. V. (1997). Decline and variability in brand loyalty. International Journal of Research in Marketing, 14(5), 405-420. DOI: 10.1016/S01678116(97)00020-7.

[13] Delgado-Ballester, E., \& Munuera-Aleman, J. L. (2000). Brand trust in the context of consumer loyalty. European Journal of Marketing, 35(11), 1238-1258. DOI: 10.1108/EUM0000000006475.

[14] Djordjevic, D., Cockalo, D., \& Bogetic, S. (2016). The Analysis of Marketing Concept Implementation in Domestic Enterprises. Journal of Engineering Management and Competitiveness, 6(2), 120-128.

[15] Elbedweihy, A. M., Jayawardhena, C., Elsharnouby, M. H., \& Elsharnouby, T. H. (2016). Customer relationship building: The role of brand attractiveness and consumer-brand identification. Journal of Business Research, 69(8), 2901-2910. DOI:10.1016/j.jbusres.2015.12.059.

[16] Fetscherin, M., \& Heinrich, D. (2014). Consumer brand relationships: A research landscape. Journal of Brand Management, 21(5), 366-371. DOI: 10.1057/bm.2014.22.

[17] Fetscherin, M., \& Heinrich, D. (2015). Consumer brand relationships research: A bibliometric citation meta-analysis. Journal of Business Research, 68(2), 380-390. DOI: 10.1016/j.jbusres.2014.06.010.

[18] Francisco-Maffezzolli, E. C., Semprebon, E., \& Muller Prado, P. H. (2014). Construing loyalty through brand experience: The mediating role of brand relationship quality. Journal of Brand Management, 21(5), 446-458. DOI:10.1057/bm.2014.16.

[19] Giovanis, A. N., \& Athanasopoulou, P. (2018). Consumer-brand relationships and brand loyalty in technology-mediated services. Journal of Retailing and Consumer Services, 40, 287-294. DOI: 10.1016/j.jretconser.2017.03.003.

[20] Habibi, M. R., Laroche, M., \& Richard, M.-O. (2014). The roles of brand community and community engagement in building brand trust on social media. Computers in Human Behavior, 37, 152-161. DOI: 10.1016/j.chb.2014.04.016.

[21] Hauke, J., \& Kossowski, T. (2011). Comparison of Values of Pearson's and Spearman's Correlation Coefficients on the Same Sets of Data. Quaestiones Geographicae, 30(2). DOI: 10.2478/v10117-0110021-1.

[22] Hemsley-Brown, J., \& Alnawas, I. (2016). Service quality and brand loyalty: The mediation effect of brand passion, brand affection and self-brand connection. International Journal of Contemporary Hospitality Management, 28(12), 2771-2794. DOI: 10.1108/IJCHM-09-2015-0466.

[23] Hudson, S., Roth, M. S., Madden, T. J., \& Hudson, R. (2015). The effects of social media on emotions, brand relationship quality, and word of mouth: An empirical study of music festival attendees. Tourism Management, 47, 68-76. DOI:10.1016/j.tourman.2014.09.001.

[24] Keller, K. L. (2009). Building strong brands in a modern marketing communications environment. Journal of Marketing Communications, 15(2-3), 139-155. DOI: 10.1080/13527260902757530.

[25] Kim, J., Morris, J. D., \& Swait, J. (2008). Antecedents of True Brand Loyalty. Journal of Advertising, 37(2), 99-117. DOI: 10.2753/joa0091-3367370208.

[26] Kim, K., Park, J., \& Kim, J. (2014). Consumer-brand relationship quality: When and how it helps brand extensions. Journal of Business Research, 67(4), 591-597. DOI: 10.1016/j.jbusres.2013.03.001.

[27] Kitic, B., Kostic-Stankovic, M., Cvijovic, J., \& Lecic-Cvetkovic, D. (2015). Environmental aspect of business communications. Management: Journal of Sustainable Business and Management Solutions in Emerging Economies, 20(74), 69-76.

[28] Kotler, P., \& Keller, K. L. (2016). Marketing Management (15 ed.). Essex, England: Pearson Education Limited.

[29] Kuikka, A., \& Laukkanen, T. (2012). Brand loyalty and the role of hedonic value. Journal of Product \& Brand Management, 21(7), 529-537. DOI: 10.1108/10610421211276277.

[30] Lin, C., Wu, W.-Y., \& Wang, Z.-F. (2000). A study of market structure: brand loyalty and brand switching behaviours for durable household appliances. International Journal of Market Research, 42(3), 277. DOI: $10.1177 / 147078530004200302$.

[31] Matzler, K., Grabner-Krauter, S., \& Bidmon, S. (2008). Risk aversion and brand loyalty: the mediating role of brand trust and brand affect. Journal of Product \& Brand Management, 17(3), 154-162. DOI: $10.1108 / 10610420810875070$. 
[32] Mishra, A., Bhusan, S., \& Dash, D. C. (2014). Linking user experience and consumer-based brand equity: the moderating role of consumer expertise and lifestyle. Journal of Product \& Brand Management, 23(4), 333-348. DOI: 10.1108/JPBM-12-2013-0459.

[33] Moller Jensen, J., \& Hansen, T. (2006). An empirical examination of brand loyalty. Journal of Product \& Brand Management, 15(7), 442-449. DOI: 10.1108/10610420610712829.

[34] Muyammil, H., Haffey, S., \& Riaz, A. (2010). Factors affecting customer satisfaction. International Research Journal of Finance and Economics, 60(1), 44-62.

[35] Park, H., \& Kim, Y.-K. (2014). The role of social network websites in the consumer-brand relationship. Journal of Retailing and Consumer Services, 21(4), 460-467. DOI: 10.1016/j.jretconser.2014.03.011.

[36] Punniyamoorthy, M., \& Prasanna Mohan Raj, M. (2007). An empirical model for brand loyalty measurement. Journal of Targeting, Measurement and Analysis for Marketing, 15(4), 222-233. DOI: 10.1057/palgrave.jt.5750044.

[37] Ramaseshan, B., \& Tsao, H.-Y. (2007). Moderating effects of the brand concept on the relationship between brand personality and perceived quality. Journal of Brand Management, 14(6), 458-466. DOI: 10.1057/palgrave.bm.2550090.

[38] Rauyruen, P., \& Miller, K. E. (2007). Relationship quality as a predictor of B2B customer loyalty. Journal of Business Research, 60(1), 21-31. DOI: 10.1016/j.jbusres.2005.11.006.

[39] Russell-Bennett, R., McColl-Kennedy, J. R., \& Coote, L. V. (2007). Involvement, satisfaction, and brand loyalty in a small business services setting. Journal of Business Research, 60(12), 1253-1260. DOI: 10.1016/j.jbusres.2007.05.001.

[40] Severi, E., \& Ling, K. C. (2013). The Mediating Effects of Brand Association, Brand Loyalty, Brand Image and Perceived Quality on Brand Equity. Asian Social Science, 9(3). DOI: 10.5539/ass.v9n3p125.

[41] Smit, E., Bronner, F., \& Tolboom, M. (2007). Brand relationship quality and its value for personal contact. Journal of Business Research, 60(6), 627-633. DOI: 10.1016/j.jbusres.2006.06.012.

[42] Theng, J., Parsons, A. G., \& Yap, S.-F. (2013). Corporate branding, emotional attachment and brand loyalty: the case of luxury fashion branding. Journal of Fashion Marketing and Management: An International Journal in Management and Social Science, 17(4), 403-423. DOI: 10.1108/JFMM-03-20130032.

[43] Torres-Moraga, E., Vasquez-Parraga, A. Z., \& Zamora-Gonzalez, J. (2008). Customer satisfaction and loyalty: start with the product, culminate with the brand. Journal of Consumer Marketing, 25(5), 302313. DOI: $10.1108 / 07363760810890534$.

[44] Veloutsou, C. (2009). Brands as relationship facilitators in consumer markets. Marketing Theory, 9(1), 127-130. DOI: 10.1177/1470593108100068.

[45] Vigneron F., \& Johnson L.W. (2017). Measuring Perceptions of Brand Luxury. In: Kapferer JN., Kernstock J., Brexendorf T., Powell S. (eds) Advances in Luxury Brand Management. Journal of Brand Management: Advanced Collections. Palgrave Macmillan, Cham. DOI: 10.1007/978-3-319-51127-6_10.

[46] Vlastelica Bakic, T., Cicvaric Kostic, S., \& Neskovic, E. (2015). Model for Managing Corporate Social Responsibility. Management: Journal Of Sustainable Business And Management Solutions In Emerging Economies, 20(74), 47-56. DOI:10.7595/management.fon.2015.0002.

[47] Zarantonello, L. P.-D., Veronique. (2016). The Handbook of Brand Management Scales: Routledge.

Received: 2018-12-19

Revisions requested: 2019-03-03

Revised: 2019-08-17 (3 times)

Accepted: 2019-08-19

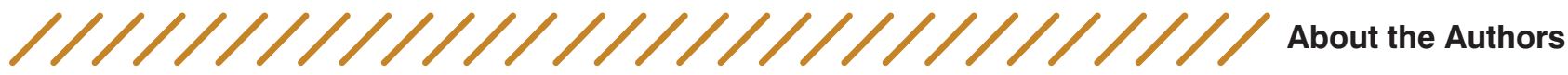

\section{Mihalj Bakator \\ University of Novi Sad, Technical Faculty "Mihajlo Pupin", Zrenjanin, Serbia mihalj.bakator@uns.ac.rs}

Mihalj Bakator has a M.Sc. degree in engineering management at the University of Novi

Sad, Technical Faculty "Mihajlo Pupin", in Zrenjanin, the Republic of Serbia. Currently, he is a Research Associate and Ph.D. student of engineering management at the University of Novi Sad, Technical faculty "Mihajlo Pupin" Zrenjanin. His areas of research interest are Marketing management, Quality management, Entrepreneurship, Consumer

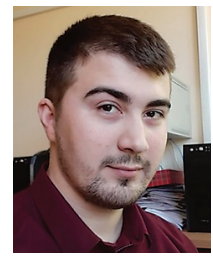
behaviour and Competitiveness. 


\section{Dejan Đorđević}

University of Novi Sad, Technical Faculty "Mihajlo Pupin”, Zrenjanin, Serbia dejan.djordjevic@ttzr.rs

Dr Dejan Đorđević has a Ph.D. in economics. He is a professor of Economics and Marketing at the University of Novi Sad, Technical Faculty "Mihajlo Pupin" in Zrenjanin, the Republic of Serbia. His main areas of research interest are Economy, Marketing, Entrepreneurship, Competitiveness and Quality management.

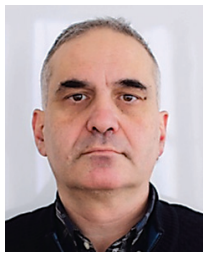

Dragan Ćoćkalo University of Novi Sad, Technical Faculty "Mihajlo Pupin", Zrenjanin, Serbia dragan.cockalo@ttzr.rs

Dr Dragan Ćoćkalo has a Ph.D. in technical sciences. $\mathrm{He}$ is an associate professor of Entrepreneurship and Quality Management at the University of Novi Sad, Technical Faculty "Mihajlo Pupin" in Zrenjanin, Republic of Serbia. His main areas of research interest are Quality management, Entrepreneurship and Regional business development.

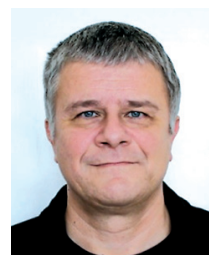

Srđan Bogetić Belgrade Business Academy of Vocational Studies, Belgrade, Serbia srdjan.bogetic@bpa.edu.rs

Dr Srđan Bogetić is a professor of vocational studies at the Belgrade Business Academy of Vocational Studies, Belgrade. In 2009. he acquired his Ph.D. degree in the domain of quality management in small and medium-sized enterprises. His areas of interest are Small and medium-sized enterprise management, Entrepreneurship, Quality management, and Business process management. 